\title{
pH-Metric Studies of Mixed Ligand Complexes of Zn(II) with Famotidine and peptides
}

\author{
SALHAH D. AL-QAHTANI \\ Department of Chemistry, College of Science, Princess Nourah bint Abdul \\ Rahman University, Riyadh, Saudi Arabia. \\ ${ }^{*}$ Corresponding author E-mail: Sunandmon00 @ yahoo.com \\ http://dx.doi.org/10.13005/ojc/330447
}

(Received: august 25, 2016; Accepted: February 02, 2017)

\begin{abstract}
Solution equilibria of the ternary complexes of $\mathrm{Zn}$ (II) with famotidine (FAM) as primary ligand and peptides $(\mathrm{L})$ as secondary ligands have been studied $\mathrm{pH}$-metrically under the experimental conditions $\left(25^{\circ} \mathrm{C}\right.$ and ionic strength I $\left.=0.10 \mathrm{~mol} / \mathrm{L} \mathrm{NaNO}_{3}\right)$. Ternary complexes are formed by a simultaneous mechanism. The concentration distribution of the complexes in solution was evaluated as a function of $\mathrm{pH}$. The values of $\Delta \log \mathrm{K}$ values for the ternary complexes have been evaluated and discussed.
\end{abstract}

Keywords: Famotidine, Peptides, Stability constants, Potentiometric titration.

\section{INTRODUCTION}

Famotidine (FAM),3-[(\{2-[(diamino methylidene)amino] -1,3-thiazol-4-yl\} methyl) sulfanyl] -N'- sulfamoyl propanimidamide, is a histamine $\mathrm{H}_{2}$ receptor antagonist that inhibits stomach acid production ${ }^{1,2}$. It is commonly used in the treatment of peptic ulcer disease and gastroesophageal reflux disease. The chemical formula of FAM together with the atomic numbering is shown in Fig. 1. Due to the presence of amino, amido and thioether groups in its structure, this drug possesses chelating properties and may interact very effectively with the essential metal ions present in blood plasma and different tissues. In the crystalline state, famotidine has two polymorphic forms that differ by arrangement of intermolecular hydrogen bonds ${ }^{3-5}$. Several binary FAM complexes containing divalent transition metal ions have been synthesized in solution as well as in the solid state ${ }^{6-8}$. Determination of stability constant of complexes with drugs are useful to know the proper dose of drug and their effect with all other components of blood stream as well as to measure the strength of metal ligand bonds ${ }^{9}$. The complexes of drugs has higher efficacy than parent drugs ${ }^{10}$. In the present investigation, the stability constants of zinc (II) complexes with famotidine(FAM) and peptides $(L)$ were studied in detail by potentiometric titration method in aqueous solutions at $25^{\circ} \mathrm{C}$ and 
<smiles>NC(N)=Nc1nc(CSCCC(N)=NS(N)(=O)=O)cs1</smiles>

Fig. 1: Chemical structure of famotidine

$\mathrm{I}=0.10 \mathrm{~mol} / \mathrm{L} \mathrm{NaNO}_{3}$. Species distribution over a range of $\mathrm{pH}$ of the complexes in solution was evaluated.

\section{EXPERIMENTAL}

\section{Materials and Reagents}

Famotidine drug (FAM), glycylglycine, glycinamide, glutamine and glycylleucine were provided by Sigma Chem. Co. All these chemical are used as received without any further purification, their purities ranged from $99-100 \%$. Zinc (II) nitrate was provided by Aldrich. The zinc content of the solution was determined accurately by titration with standard EDTA $^{11}$. The $\mathrm{NaOH}$ solution used for the titrations was determined with potassium hydrogen phthalate (Merck Chem. Co.). All solutions were prepared in deionized water.

\section{Apparatus}

The potentiometric measurements were made using a Griffin $\mathrm{pH}$ J-300-010 G Digital pH meter. The electrode was calibrated with standard buffer solutions $(\mathrm{pH} 4.0$ and 10.0) before the $\mathrm{pH}$ measurements at $25^{\circ} \mathrm{C} \pm 0.1^{\circ} \mathrm{C}$.

\section{Potentiometric Procedure and Measurements}

For equilibrium studies, the following solutions were prepared and titrated potentiometrically against standard carbonate- free $\mathrm{NaOH} 0.05 \mathrm{~mol} / \mathrm{L}$ solution:

- $\quad 40 \mathrm{~cm}^{3}$ of a solution mixture containing $\left(1.25 \times 10^{-3} \mathrm{~mol} / \mathrm{L}\right)$ ligands and $0.1 \mathrm{~mol} / \mathrm{L}$ $\mathrm{NaNO}_{3}$

- $\quad 40 \mathrm{~cm}^{3}$ of a solution mixture containing $\mathrm{Zn}$ (II) $\left(1.25 \times 10^{-3} \mathrm{~mol} / \mathrm{L}\right)$, the ligands $\left(3.75 \times 10^{13}\right.$ $\mathrm{mol} / \mathrm{L}$ ) in the molar ratio of $1: 3$ and $\mathrm{NaNO}_{3}$ $(0.1 \mathrm{~mol} / \mathrm{L})]$

- $\quad 40 \mathrm{~cm}^{3}$ of $40 \mathrm{ml}$ of a solution mixture containing $\mathrm{Zn}(\mathrm{II})$, FMA and other ligands, all of concentration $\left(1.25 \times 10^{-3} \mathrm{~mol} / \mathrm{L}\right)$ and $0.1 \mathrm{~mol} / \mathrm{L}$ $\mathrm{NaNO}_{3} . \mathrm{HNO}_{3}$ solution was added, so that they were fully protonated at the beginning of the titrations.
The protonation constants of FAM (or $\mathrm{L}$ ) were determined by titration of mixture $(A)$. The formation constants of $\mathrm{Zn}(\mathrm{II})-\mathrm{FAM}$ and $\mathrm{Zn}(\mathrm{II})-\mathrm{L}$ complexes were determined by titration of mixture (C). The respective stability constants of $\mathrm{Zn}(\mathrm{II})$ FAM- $L$ for the ternary complexes were determined by titration of mixture $(C)$. The ionic strength was kept constant $(0.10 \mathrm{~mol} / \mathrm{L})$ using a $\mathrm{NaNO}_{3}$ solution, and a total volume of $40 \mathrm{~cm}^{-3}$ was used for each titration. $[\mathrm{OH}]$ values were calculated using a $\mathrm{pK}_{w}$ value of $13.87 \pm 0.05$ at $25^{\circ} \mathrm{C}$. There was no precipitation with in the $\mathrm{pH}$ range at which the titrations performed. For all the titrations, $\mathrm{HNO}_{3}$ solution was added, so that they were fully protonated at the beginning of the titrations.

\section{Computer analysis of titration data}

The stoichiometries and stability constants of the complex species formed in solution were determined by examining various possible composition models for the systems studied. About 110 to 150 experimental data points were available for evaluation in each run. All the dissociation and the complex formation constants were determined using the HYPERQUAD program ${ }^{12}$ and the speciation as a function of $\mathrm{pH}$ using the HYSS program ${ }^{13}$.

Equilibrium constants evaluated from the titration data (table 1) are defined by equations (1) and (2).

$$
\begin{aligned}
& \left.(\mathrm{L})_{\mathrm{q}}^{\mathrm{I}(\mathrm{Zn})}+\mathrm{H}\right)_{\mathrm{r}}(\mathrm{FAM})+\mathrm{q}(\mathrm{L})+\mathrm{r}(\mathrm{H}) \rightleftharpoons(\mathrm{Zn})_{1}(\text { FAM })_{\mathrm{p}} \\
& \beta_{\text {Ipqr }}=\frac{\left[(\mathrm{Zn})_{l}(\mathrm{FAM})_{\mathrm{p}}(\mathrm{L})_{\mathrm{q}}(\mathrm{H})_{\mathrm{r}}\right]}{[\mathrm{Zn}]^{\mathrm{I}}[\mathrm{FAM}]^{\mathrm{p}}[\mathrm{L}]^{\mathrm{q}}[\mathrm{H}]^{r}}
\end{aligned}
$$

(charges are omitted for simplicity)

Where I, p, q and $r$ are the stoichiometric coefficients corresponding to the zinc(II) ion, famotidine (FAM), peptides (L) and proton, respectively 


\section{RESULTS AND DISCUSSION}

\section{Proton- FAM ligand system}

The proton dissociation constants of the FAM ligand were calculated by fitting the volume$\mathrm{pH}$ data, to the HYPERQUAD program and these constants are tabulated in Table 1. Three protonation sites are possible in FAM as shown in Figure 1. Only two deprotonation steps, can be determined for FAM in the fully protonated form in the titrable $\mathrm{pH}$ range at the guanidine and thiazole nitrogens with $\mathrm{pKa}$ values of 11.08 and 6.75 , respectively.

\section{Binary Complexes}

In all titration curves the $\mathrm{Zn}(\mathrm{II})$ - ligand complex is lowered from that of the free ligand curve, indicating formation of $\mathrm{Zn}$ (II) complex by displacement of protons. The calculated stability constants of binary complexes of FAM drug and peptides with $\mathrm{Zn}(\mathrm{II})$ are presented (Table 1). The formation constants were determined by fitting potentiometric data on the basis of possible composition models. The selected model with the best statistical fit was found to consist of $\mathrm{Zn}(\mathrm{L})$ (1010), Zn (L) $)_{2}(1020), \mathrm{Zn}\left(\mathrm{H}_{-1} \mathrm{~L}\right)(101-1), \mathrm{Zn}$ (FAM)

Table 1: Formation constants of the binary and ternary complexes in the $\mathrm{Zn}$ (II)-FAM- peptides systems at $25 æ \% \mathrm{C}$ and $0.1 \mathrm{~mol} / \mathrm{L}$ ionic strength

\begin{tabular}{|c|c|c|c|c|c|c|c|c|}
\hline System & I & $p$ & $q$ & $\mathbf{r}^{\mathrm{a}}$ & $\log \beta^{b}$ & $\log K$ & $\Delta \log K$ & \% R.S \\
\hline \multirow[t]{5}{*}{ FAM } & 0 & 1 & 0 & 1 & $11.08(0.03)$ & & & \\
\hline & 0 & 1 & 0 & 2 & $17.83(0.02)$ & & & \\
\hline & 1 & 1 & 0 & 0 & $5.32(0.01)$ & & & \\
\hline & 1 & 1 & 0 & 1 & $12.66(0.02)$ & & & \\
\hline & 1 & 1 & 0 & -2 & $-11.14(0.04)$ & & & \\
\hline \multirow[t]{6}{*}{ Glycylglycine } & 0 & 0 & 1 & 1 & $7.97(0.01)$ & 4.66 & 0.64 & 15.92 \\
\hline & 0 & 0 & 1 & 2 & $10.55(0.01)$ & & & \\
\hline & 1 & 0 & 1 & 0 & $4.02(0.01)$ & & & \\
\hline & 1 & 0 & 2 & 0 & $7.12(0.02)$ & & & \\
\hline & 1 & 0 & 1 & -1 & $1.53(0.01)$ & & & \\
\hline & 1 & 1 & 1 & 0 & $9.98(0.03)$ & & & \\
\hline \multirow[t]{5}{*}{ Glycinamide } & 0 & 0 & 1 & 1 & $7.69(0.01)$ & 3.59 & 0.14 & 4.06 \\
\hline & 1 & 0 & 1 & 0 & $3.45(0.01)$ & & & \\
\hline & 1 & 0 & 2 & 0 & $6.52(0.01)$ & & & \\
\hline & 1 & 0 & 1 & -1 & $-1.03(0.01)$ & & & \\
\hline & 1 & 1 & 1 & 0 & $8.91(0.03)$ & & & \\
\hline \multirow[t]{6}{*}{ Glutamine } & 0 & 0 & 1 & 1 & $8.95(0.01)$ & 5.13 & 0.44 & 9.38 \\
\hline & 0 & 0 & 1 & 2 & $11.12(0.01)$ & & & \\
\hline & 1 & 0 & 1 & 0 & $4.69(0.04)$ & & & \\
\hline & 1 & 0 & 2 & 0 & 7.45(0.01) & & & \\
\hline & 1 & 0 & 1 & -1 & $-0.89(0.01)$ & & & \\
\hline & 1 & 1 & 1 & 0 & $10.45(0.02)$ & & & \\
\hline \multirow[t]{6}{*}{ Glycylleucine } & 0 & 0 & 1 & 1 & $8.13(0.00)$ & 4.46 & 0.27 & 6.44 \\
\hline & 0 & 0 & 1 & 2 & $11.04(0.02)$ & & & \\
\hline & 1 & 0 & 1 & 0 & $4.19(0.01)$ & & & \\
\hline & 1 & 0 & 2 & 0 & $7.18(0.01)$ & & & \\
\hline & 1 & 0 & 1 & -1 & $1.40(0.01)$ & & & \\
\hline & 1 & 1 & 1 & 0 & $9.78(0.01)$ & & & \\
\hline
\end{tabular}

al, $p$ and $q$ are the stoichiometric coefficient corresponding to $\mathrm{Zn}(\mathrm{II})$, ýFAMý or peptides and $\mathrm{H}^{+}$, respectively. ${ }^{\mathrm{b}}$ standard deviations are given in parentheses. 


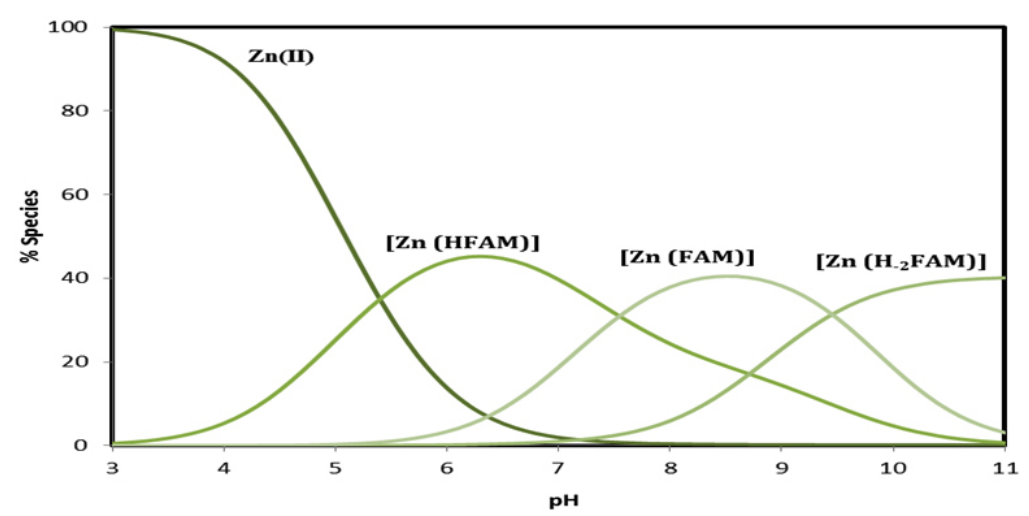

Fig. 2: Percentage distribution curves of $\mathrm{Zn}(\mathrm{II})-\mathrm{FAM}$ systems

(1100), Zn ( $\mathrm{H}_{-2}$ FAM) (110-2) and Zn(HFAM) (1101) complexes. The concentration distribution diagram of $\mathrm{Zn}$ (II)-FAM system is shown in Fig. 2. The concentration of the 1100 species increases with increasing $\mathrm{pH}$, attaining a maximum of $41.0 \%$ at $\mathrm{pH}$ 8.5. Further increase in $\mathrm{pH}$ is accompanied by a decrease in the concentration of the 1100 species and an increase in the concentration of the $\mathrm{Zn}\left(\mathrm{H}_{-2}\right.$ FAM) (110-2) species. Zn(HFAM) (1101) complex species has been found to be most favoured at lower $\mathrm{pH}$ values.

\section{Ternary Complexes Involving $\mathrm{Zn}^{2+}$, FAM and Peptides}

The ternary complex formation involving $\mathrm{Zn}(\mathrm{II}), \mathrm{FAM}$ and peptides were characterized by fitting their potentiometric data to various models. The most acceptable model was found to be consistent with the formation of the complexes with stoichiometric coefûcients 1110 and 111-1. On increasing the $\mathrm{pH}$, the coordination sites should switch from the carbonyl oxygen to the amide nitrogen. Such a change in coordination centers is now well documented ${ }^{14}$, 15. The amide groups undergo deprotonation and the $[\mathrm{Zn}(\mathrm{FAM})(\mathrm{LHH} 1)]$ complexes are formed. The glutamine complex is more stable than the glycinamide complex. The most likely explanation lies in the fact that glutaminate carries a negative charge, whereas glycinamide is neutral. The electrostatic interaction between the glutaminate and the positively charged $\mathrm{Zn}$ (II) complex would result in a lowering of the free energy of formation. Estimation of the concentration distribution of the various species in solution is a useful mean for elucidating the extent of $\mathrm{Zn}(\mathrm{II})$ binding capacity toward the primary and secondary ligands. The concentration distribution of the ternary complex formed with peptides attained values ranging from about $88 \%$ to $99.9 \%$ along the $\mathrm{pH}$ range 7.6-10.2. The equilibrium concentration distribution diagrams of the various complex species provide a useful picture of $\mathrm{Zn}(\mathrm{II})$ binding in the physiological $\mathrm{pH}$ range.

The parameter $\Delta \log \mathrm{K}$ values are generally used to indicate the relative stability of the ternary complexes as compared to the binary ones as in equations:

$\mathrm{Zn}(\mathrm{FAM})+\mathrm{Zn}(\mathrm{L}) \rightleftharpoons \mathrm{Zn}(\mathrm{FAM})(\mathrm{L})+\mathrm{Zn}$

$\Delta \log K=\log K_{Z n(F A M) L}^{Z n(F A M)}-\left(\log K_{Z n(F M A)}^{Z n}+\log K_{Z n(L)}^{Z n}\right)$

The $\Delta \log \mathrm{K}$ values (Table 1) are positive, showing that the ternary ýcomplexes are more stable than the corresponding binary complexes, and this may be attributed to inter ligand interactions occur in the ternary complexes.

The percent relative stabilization (\% R.S.), to quantify stability of a ternary complex, may be defined as ${ }^{16}$ :

$$
\left\lfloor\left(\log \mathrm{K}_{\mathrm{Zn}(\mathrm{FAM}) \mathrm{L}}^{(\mathrm{FAM})}-{ }^{-\log \mathrm{K}} \begin{array}{l}
\mathrm{Zn} \\
\mathrm{Zn}(\mathrm{L})
\end{array}\right) / \log \mathrm{K}_{\mathrm{Zn}(\mathrm{L})}^{\mathrm{Zn}}\right\rfloor \times 100
$$

The values of $\%$ R.S. have been calculated (Table 1). For all systems, the parameter \% R.S. is positive. This may be considered as evidence for the occurrence of enhanced stabilities. Positive values of $\%$ R.S. agree with the $\Delta$ log K values. 


\section{CONCLUSIONS}

The formation constants of the various complexes of $\mathrm{Zn}(\mathrm{II})$, FAM and peptides were determined potentiometrically at $25^{\circ} \mathrm{C}$ and ionic strength $0.1 \mathrm{M} \mathrm{NaNO}_{3}$. Ternary complexes are formed in a simultaneous mechanism. The formation constant values of the ternary complexes show that the $\mathrm{Zn}(\mathrm{II})$-FAM-peptides ternary complexes are more stable than the 1:1 $\mathrm{Zn}(\mathrm{II})$-FAM or $\mathrm{Zn}(\mathrm{II})$ peptides binary complexes. Thus the $1: 1 \mathrm{Zn}(\mathrm{II})$-FAM complex has a greater tendency toward combination with peptide molecule. The positive value of $\Delta$ log $K$ is attributed to the extra stability of the ternary complexes.

\section{REFERENCES}

1. Malgorzata, B.; Wiesªw, £.; Henryk, K.; Leonard, M. P. Journal of Inorganic. Biochemistry 2004, 98, 995-1001

2. Ganellin, C. R; Parsons, M.E. Pharmacology of Histamine Receptors, J. Wright and Sons, Bristol. 1982

3. Van der Goot, H. ; Bast, A.; ýTimmerman, H. Handbook of Experimental Pharmacology, Springer, Berlin vol. 97 (chap.18). 1991

4. Ishida, T.; In, Y.; Doi,ý M.; Inoue, M.; Yanagisawa, I. Acta Crystallographica B 1989, 45, 505-512.

5. Barañska M .,PhD thesis, Jagiellonian University, Krakôw. 1998

6. Onoa, G. B.; Moreno, V. Journal of Inorganic Biochemistry 1998, 72,141-153.

7. Malgorzata, B.; Elzbieta, G. K; Henryk, K.; Leonard, M. P. Journal of Inorganic Biochemistry 2002, 92: 112-120

8. Maria, K.; Anna, M. D.; Maria, L. G. J. Chem.
Soc., Dalton Trans. 1996, 1905-1908

9. Thomas, G. Medicinal Chemistry, John Wiley and Son Co. Ltd. London. 2002

10. Sapse, A. M.; Jain, D. C. Quantum Chemistry 1988, 33: 69-76.

11. Vogel, Quantitative chemical analysis,"ý 5th Edition, Longman, UK. 1989

12. Gans, P.; Sabatini, A.; Vacca, A. Talanta 1996, 43: 1739-1753.

13. Gans, P.; lenco, A.; Peters, D.; Sabatini, A.; Vacca, A. Coordination Chemistry Reviews, 1999, 184, 311-318.

14. Sovago, I. in K. Burger, (Ed.), Biocoordination Chemistry, Ellis Horwood, Chichester. 1990

15. Pettit, L. D; Gregor, J. E.; Kozlowski, H. Prespectives in Bioinorganic Chemistry, Jai Press. Ltd. 1991

16. Khalil, M. M.; Radalla, A. M. Talanta 1998, 46: 53-61. 